\title{
ENGINEERING GEOLOGICAL AND GEOPHYSICAL INVESTIGATIONS OF A SLOPE FAILURE AT EDINBURGH CASTLE, SCOTLAND
}

\author{
L J Donnelly ${ }^{1}$, M G Culshaw ${ }^{2}$, P R N Hobbs ${ }^{3}$, R C Flint ${ }^{4}$ and P D Jackson ${ }^{3}$ \\ ${ }^{1}$ Halcrow Group Ltd., Deanway Technology Centre, Wilmslow Road, Handforth, Cheshire, SK9 3FB, \\ UK, formerly British Geological Survey, Keyworth, Nottingham, NG12 5GG, UK \\ ${ }^{2}$ British Geological Survey, Keyworth, Nottingham, NG12 5GG, UK and Faculty of Construction, \\ Computing and Technology, The Nottingham Trent University, Newton Building, Burton Street, \\ Nottingham NG1 4BU, UK \\ ${ }^{3}$ British Geological Survey, Keyworth, Nottingham, NG12 5GG, UK \\ ${ }^{4}$ Department of Aeronautical and Automative Engineering, University of Loughborough, \\ Leicestershire, LE11 3TU, UK, formerly British Geological Survey, Keyworth, Nottingham, NG12 \\ $5 G G, U K$ \\ Communicating author: L J Donnelly; email: DonnellyLJ@halcrow.com; Tel: +44(0)1625 540456; \\ Fax: +44(0)1625 549325
}

\section{ABSTRACT}

Edinburgh Castle is one of Scotland's most important heritage sites. Geologically, the site is also unusual. Glacial erosion has produced a classic 'crag and tail' structure. The crag consists of columnar jointed basalt and the tail of sediments protected from glacial erosion by the 'crag' to form a gentle slope.

In 1997 apparent instability was observed on the southern side of the 'tail' between the Edinburgh Castle Esplanade and Johnston Terrace. In 1998 geotechnical and geological investigations were undertaken to investigate the instability of this slope. These included a review of historical records and reports of previous site investigations, the excavation of four trial pits, an electrical resistivity survey and detailed geomorphological observations to document ground movements.

A shallow slope failure was proven to have taken place within saturated, layered, cohesive to noncohesive, loose to dense heterogeneous fill on a slope of $44^{\circ}$. The date of the initial failure is not known, but is likely to have taken place over a period of many years, since at least the 1950's.

Remediation works were subsequently undertaken to stabilise the slope and these mainly consisted of the installation of soil nails, a bi-axial geo-grid and minor filling to mitigate the effects of the ground movements and to facilitate repair of the retaining wall.

KEYWORDS: Edinburgh Castle, historic monument, slope instability, site investigation, remediation

\section{INTRODUCTION}

Edinburgh Castle forms the focal point of the City of Edinburgh. It is arguably the best-known landmark in the country, with evidence of occupation since about $900 \mathrm{BC}$ and the first record of a siege in AD 1093. It is one of Scotland's main tourist attractions, and attracts over one million visitors each year as well as forming the focal point for the annual military tattoo.

As a result of glacial erosion during the Pleistocene (2.0 Ma to approximately 10,000 years BP) Castle Hill and the Royal Mile have been left as a classic example of a structure known as a 'crag and tail.' The 'tail,' composed of sediments protected from glacial erosion by the 'crag,' formed a gentle slope (the Royal Mile) leading in an easterly direction from the Castle.

In 1997, apparent instability was observed on the southern side of the 'tail' between the Edinburgh Castle Esplanade and Johnston Terrace. Particular concern was expressed about the stability of the slope in the vicinity of the main retaining wall below the Esplanade where minor instability had occurred with the movement of material downslope (Figure 1). A site inspection was carried out to 
enable the design of a suitable geophysical and engineering geological investigation to assess the ground conditions and the stability of the slope (Donnelly et al., 1998).

This paper reviews various engineering geological investigations at Edinburgh Castle, such as those for the Castle Tunnel and the Military Tattoo, and describes the ground investigations that were undertaken to investigate the instability between the Esplanade and Johnston Terrace. An assessment of the stability of the slope is presented and the possible remedial measures are discussed.

\section{GEOLOGY}

The geology of Edinburgh Castle has been described in detail by several authors (for example, Tait [1945], Mitchell et al. [1960], Mitchell and Mykura [1962], Sissons [1971], MacClaren [1984], Davies [1991] and Ruckley [1997]) and has been mapped on British Geological Survey 1:10 560 scale geological sheets NT27 SW \& SE (British Geological Survey, 1965) (Figure 2a and b).

The Castle is situated on an eroded remnant of a basaltic plug, from the central vent of a Palaeozoic volcano. The plug intrudes, almost vertically, through a sequence of well-bedded sedimentary strata of Lower Carboniferous (Dinantian) age (approximately 345 Million years ago Ma). The volcanic plug, often referred to as Castle Rock, reaches a maximum elevation of approximately $60 \mathrm{~m}$ above the surrounding area. It is oval in shape and elongated in a NW to SE direction. The axis of the plug is tilted from the vertical towards the southeast (Cheeney, 1977). The plug is not a single intrusive event, but represents a series of intrusions, since the chilled margins of the basalt plug are not confined to the intrusion's outer limit. The plug consists of a microporphyritic basalt of Lower Carboniferous age. It has a fine-grained groundmass, consisting of plagioclase feldspar, augite and magnetite, with phenocrysts of altered olivine and augite; sulphide mineralisation also occurs in the basalt and is most probably in the form of pyrite. The actual extent of the plug is difficult to determine due to the presence of post-glacial drift deposits. The plug contains well-developed columnar jointing sets, with several secondary and tertiary joint trends.

On the eastern side of the plug the sedimentary rocks form a terrace (the Esplanade). This has been utilised as a military defence and continues in an easterly direction, connecting with the Royal Mile. The sedimentary sequence forms the Cementstone Group, of Carboniferous age. The strata at depth beneath the terrace are reported to consist of alternating sequences of sandstones each between 0.3 and $0.6 \mathrm{~m}$ thick, which are interbedded with siltstones and shales with highly variable geotechnical properties. Adjacent to the plug the strata have been affected by contact metamorphism. The metamorphosed zone consists of hornfelsed, greenish, marly shales. The edge of the plug can be recognised by the presence of a chilled margin or a peripheral jointed zone.

Towards the western end of the Esplanade, the sequence of sedimentary rocks is displaced by a northeast trending fault, the Castle Hill Fault. This fault is estimated to be of late Carboniferous age (Ruckley, 1997). The fault is exposed on a partially vegetated slope below the southern side of the Half Moon Battery. At this locality down-faulted strata between the fault and the eastern margin of the plug dip steeply at around $30-40^{\circ}$ towards the northwest. East of the fault, the strata dip gently in an easterly direction and can also be observed on the south-facing slope below the Esplanade.

The oversteepened valleys that surround the plug are partially filled with glacial and post-glacial deposits, suggesting that they were once occupied by glaciers. During the Pleistocene, the ice sheets moved from the west and impinged on the western face of the basaltic plug. Essentially, Castle Rock acted as an obstruction to the advancing ice, forcing the ice-sheets to become deflected around the volcanic plug, to the north and the south. These excavated the valley now occupied by Princes Street Gardens and the railway line leading to Waverley Station. The ice deflected to the south excavated the valley occupied by the Grassmarket and the Cowgate. The 'tail,' composed of sediments protected from glacial erosion by the 'crag,' formed a gentle slope (the Royal Mile) leading in an easterly direction from the Castle. According to Davies (1991) the tail contains superficial deposits of till masked by a substantial thickness of infill material, which has accumulated since the Middle Ages. 
A complex post-glacial landslide occurs on the north-facing slope of the tail, beneath the Esplanade. This occurs within the Princes Street Gardens. This landslide has developed in glacial till largely due to over-steepening by glaciation. The valley to the north of the landslide was once occupied by a glacial lake and subsequently by a smaller artificial lake between 1450 and 1816 .

The basalt on which the Castle stands is a poor aquifer. Groundwater flow is controlled by the density, orientation and openness of the jointing within the rock mass. During stabilisation works in 1967, a level of permanent water saturation was recorded about $15 \mathrm{~m}$ above the footpath west of the Well House Tower (Ruckley, 1991). However, none of the water wells on this plug are sunk to this depth. Numerous springs have been reported at the foot of the Castle Rock or close to its base. This suggests that the groundwater table in the sedimentary rocks and fill surrounding the plug is at, or close to the present ground level.

\section{ENGINEERING GEOLOGY OF EDINBURGH CASTLE}

\section{Instability on Castle Rock}

The most comprehensive account of the engineering geology of Edinburgh Castle Rock was by Price and Knill (1967). In the 1960s, periodic falls of basalt blocks occurred in close proximity to public roads, railways and parks. Since this presented a potential hazard to members of the public, considerable attention was given to the identification of failure mechanisms and subsequent stabilisation and preventative techniques.

The failure of Castle Rock was found to be controlled by the orientation and frequency of the rock mass discontinuities. In general, the loosening of strong, unweathered, basalt blocks was attributed to weathering along joint surfaces as a result of plant wedging and freeze-thaw crystallisation in the colder winter months. This was a near-surface effect that did not penetrate the rock mass to any significant depth. Therefore, large-scale failure of the Castle rock was not thought likely (Price and Knill, 1967). Rock bolting, grouting and drainage provided satisfactory means of reducing the hazard of disintegration of the Castle Rock, although in some instances high stress concentrations around expanding rock anchors could, in certain circumstances, have a detrimental effect on stability.

\section{Castle Rock Service Tunnel}

In the 1980's, a service tunnel was excavated through Castle Rock to enable the diversion of vehicular traffic and services, such as the water supply, and to provide access for emergency vehicles. The tunnel was constructed with an overall length of $164 \mathrm{~m}$, of which $97 \mathrm{~m}$ ran through Castle Rock with the remaining length being cut-and-cover reinforced concrete structures. An investigation was undertaken to determine the geological conditions for the tunnel, details of which were provided by Davies (1991). This included a desk study of available Castle and geological records, geological mapping of the area and tunnel route, trial pits and borehole drilling into the post-glacial landslide area. These investigations confirmed the feasibility of the tunnel.

In geotechnical terms the tunnelling operations found the following:

- The basalt rock is intrinsically strong and remarkably fresh. However, deterioration occurs near the plug margin, due to the chilling effect. This has tended to improve the quality of the sedimentary rocks in terms of their competence, probably due to contact metamorphism, mainly thermal alteration.

- The basalt rock mass exhibited lower strength than expected from laboratory testing. Failure occurred along yellow-stained microfissures, which were found to contain penninitic chlorite from $\mathrm{x}$-ray diffraction analysis. 
- The jointing pattern was difficult to predict and three sets of joints were recognised - radial, dome and circumferential (Price and Knill, 1967). The rock is non-magnetic and so joint orientations could be readily measured with a compass.

During construction in 1988 the sedimentary strata were found to contain open and clay-filled joints. The basalt/sedimentary interface was found to be a tight 'welded' discontinuity. Rock bolting and reinforced sprayed concrete was necessary during construction to stabilise the rock mass. A more detailed account of the engineering aspects was given by Douglas and Keeble (1990).

\section{Military Tattoo Spectator Stands}

In 1975 a site investigation was carried out for the site of the proposed spectator stands for the Edinburgh Military Tattoo. The investigation was required to determine the geology of the site, to determine any difficulties that might arise during construction as a result of the ground conditions, to present data required for the foundation design and to make recommendations based on the information available.

\section{Site investigation}

The site investigation for the stands included borehole drilling and sampling, consolidation tests, particle size analyses, and shear box tests (Nicholson, 1975). A total of twenty seven light cable percussion boreholes were drilled within the Castle Esplanade area on the terrace overlooking Princes Street Gardens, and at the top of the Johnston Terrace slope. The boreholes were sunk to various depths, the majority terminating in sandstone. However, the sandstone was not cored and was proved only by percussion methods to a depth of about a metre. In most of the boreholes the sandstone was overlain by a layer of softer, decomposed shale or weathered sandstone, which probably represents a zone of weathered bedrock.

\section{Boreholes}

In a north-south direction, the boreholes revealed bedrock to lie close to the surface on the line of boreholes 13-17. The upper surface of the bedrock gently fell away towards the north, between boreholes 9-12, but fell much more steeply, between boreholes 1-18, 2-19 and 3-20 (Figure 3).

In an east-west direction, the bedrock lay deepest in the west, being at almost $14 \mathrm{~m}$ at borehole 23 (Figure 3). It rose rapidly between boreholes 12-11, 23-24 and 13-14 (Figure 3). To the east the gradient of the bedrock surface was uniform and flat. Rock was not reached within the $13.6 \mathrm{~m}$ drilled in borehole 20, at the top of the Johnston Terrace slope. However, rock was encountered at shallower depths in the two adjacent boreholes, 19 and 21 (Figure 3). Furthermore, boreholes located directly north of borehole 20, that is, boreholes 3,15 and 25, indicated the bedrock to occur slightly deeper.

Strata comprising sandy clay and gravel were encountered in some boreholes. These were described as being of firm to stiff consistency and rarely more than a metre or two in thickness, and found overlying the rock. This may represent glacial drift or other Pleistocene deposits.

The majority of the borehole logs describe the strata above the sandstone as fill, consisting of a wide variety of materials. Most of the fill consisted of sandy clay, gravel, ashes, rubble, broken bedrock and sandstone. The boreholes showed the thickness of fill beneath the Esplanade to be in the order of $9 \mathrm{~m}$ between boreholes 1 and 13, and 23 and 25. On the south side of the South Esplanade Wall fill in excess of $10 \mathrm{~m}$ was found in boreholes 18-20. In the north almost $9 \mathrm{~m}$ of fill was found at borehole 12 . The fill beneath the Esplanade is thought to be of considerable age, dating back to the early 1900's or before. 


\section{Standard Penetration Tests}

Standard Penetration Tests (SPT) were carried out at intervals in each borehole to obtain a measure of the relative density of the various materials encountered. This gave an indication of their safe bearing capacity. In general, a uniform set of results was obtained, which defined the zones of fill, weathered and unweathered bedrock. The results of the tests show the range of ' $N$ ' values and corresponding safe bearing capacities for square bases (qs) and suggested average values of qs. The results of these are summarised in Table 1.

The SPT's gave reasonably uniform results in the fill with most of the ' $\mathrm{N}$ ' values lying between 10 and 15. However, a few lower results were recorded, most noticeably in the deeper, softer clay fill in boreholes 12 and 13 to 16.

\section{Undrained Triaxial Compression Tests}

Undisturbed samples were collected from twelve of the boreholes and tested under laboratory conditions. They were subject to undrained triaxial compression tests to determine shear strength and safe bearing capacity. The results are these tests are presented in Table 2.

The indicated safe bearing capacities obtained from the laboratory tests on the samples of clay fill and natural clays were, in general, of a similar magnitude to those indicated from the SPT results. The main differences were in boreholes $6(3 \mathrm{~m}), 12(5.25 \mathrm{~m})$ and $23(6.5 \mathrm{~m})$, where the triaxial test results were lower and in boreholes $4(3.5 \mathrm{~m}), 5(1.5 \mathrm{~m})$ and $7(2.2 \mathrm{~m})$, where the triaxial test results were higher. In boreholes 13-16 the triaxial test bearing values were also higher than the corresponding SPT results in the more granular fill.

\section{Undrained Shear Box}

Undrained shear box tests were carried out on various samples of fill to determine the shear strength parameters (cohesion and internal friction angles) in terms of effective stresses. The results are these are presented in Table 3.

\section{Atterberg Limits}

The Atterberg limit test results on the majority of the 22 samples tested showed the majority of the fill material to be clay of low plasticity, with the liquid limits generally between 25 and $30 \%$, with some local variations. Two samples in the soft to firm sandy clays from deeper in boreholes 13 and 23 had higher liquid limits (36\%) and slightly wider plasticity index ranges (12-15\%), indicative of a more plastic material. Three samples from boreholes 14, 21 and 23 were cohesionless giving liquid limits between 20 and 25\%, together with a plasticity index of 4-6\%. The natural moisture content of the fill samples were in the range of $15-25 \%$, with one or two higher or lower values, for example, $34 \%$ in borehole $12(5.25 \mathrm{~m})$ and $31 \%$ in borehole $23(6.50 \mathrm{~m})$.

The Atterberg limits for the naturally deposited sandy clays, above the bedrock, were variable. Some of the material was classified as clay of medium to low plasticity (boreholes 4 and 10), with typical liquid and plastic limits of 34 and 21\% respectively. The samples from boreholes 7, 8 and 9 were more sandy containing little cohesive material, the liquid and plastic limits being approximately 20 and $16 \%$. The remainder of the samples (such as from borehole 10) gave intermediate values.

The natural moisture content generally lay between 10 and 20\%, at or below the plastic limit of the soils with one exception; a sample from borehole 2, a stiff, sandy clay, had a higher moisture content of $23 \%$. This sample had the lowest shear strength of all the natural sandy clays tested.

\section{Bulk Density}


The natural bulk density of the samples of fill ranged from between $1.90 \mathrm{and} 2.10 \mathrm{Mg} / \mathrm{m}^{3}$. The naturally deposited sandy clays had higher bulk densities averaging over $2.10 \mathrm{Mg} / \mathrm{m}^{3}$.

\section{Particle Size Distribution}

Particle size distributions were determined for sixteen samples of fill. Although there were variations in the results, half the samples had a combined silt and clay content of between 15-25\%. Almost three quarters of the tests showed a gravel fraction of $25-50 \%$. Much of the material was fairly well graded.

\section{Consolidation Tests}

Consolidation tests were carried out on seven samples. The most compressible of the samples tested were the loose, clayey sand and gravel fill. For both the fill and naturally deposited soils, the timedisplacement plots indicated that the proportion of immediate compression was quite high, amounting to some $50-75 \%$ of the total consolidation.

\section{Chemical Tests and $\mathrm{pH}$}

Chemical tests gave $\mathrm{pH}$ values that were slightly alkaline $(\mathrm{pH}=7.5$ or 8.0$)$. Sulphate content varied with most of the samples tested having quite low concentrations of soluble sulphate between 0.015 and $0.35 \%$. The results did not indicate any necessity for special measures to protect buried concrete from chemical attack.

\section{Piling}

The site investigation recommended that piling would be necessary to the south and north stand rear foundations but that the remaining foundations could be constructed at the surface. It was advised that the piles should penetrate any layers of weathered rock. Furthermore, rock anchors were recommended to resist horizontal forces that acted in a southerly direction, towards the Johnston Terrace slope. The site investigation report (Nicholson, 1975) further stated that in other directions the passive resistance of the fill would be mobilised.

\section{ESPLANADE TO JOHNSTON TERRACE SLOPE INSTABILITY}

Following the observation in 1997 of apparent instability beneath the Esplanade and above Johnston Terrace, a walk-over survey and site inspection was carried out on for Historic Scotland who now had responsibility for the maintenance of the Castle. This was followed by a desk study and ground investigation. The objectives of the site investigation were:

- To identify areas of slope movement where there may be a risk of slope failure.

- To identify areas of slope instability, which may pose a threat to the esplanade structure and/or the general public.

- To record any aspects of slope failure including landslide scars, fissures and groundwater seepages etc.

- To suggest any necessary remediation of any areas of instability that were identified.

- To advise whether further geological, geotechnical or geophysical investigations were necessary.

The objectives were met by adopting the following methodology: 
- Undertaking a desk study to collate information on the geology, previous site investigations and the history of development of the site.

- Undertaking a visual inspection of the ground conditions.

- Excavating a series of shallow trial pits to allow observations of the near-surface geology.

- Carrying out a geophysical survey using a shallow electrical resistivity method to identify variations in the nature of the near-surface deposits.

\section{Desk Study and Historical Review}

A review of previous land-use was considered to be highly significant in this study. This is recommended by the Building Research Establishment for building on fill (Charles, 1993). Edinburgh Castle has a long recorded history, and an even longer unrecorded one. Evidence of the history of the Castle of the early Middle Ages survives only in a few references, the earliest information being available from about 1093. The main objective of undertaking an historical assessment of Edinburgh Castle was to determine, as far as is possible, the evolution of the 'tail' structure upon which the Esplanade is located. Early historical information cannot be relied upon since sketches and plans were often not drawn to any recognisable scale, or they included structures that did not exist and clearly represented development plans that were never implemented. For example, a view of Edinburgh showing damage by Hertford's army in 1544, suggested that the 'tail' was populated by villages and residential buildings up to the castle wall (Driscoll and Yeoman 1997). Another diagram, from around 1700 (Figure 4) displays external defensive walls on the 'tail' that were never built. A diagram from 1647 (Figure 5) suggested that silted-up medieval ditches and cannon batteries might have been excavated into the original 'tail' bedrock (Driscoll and Yeoman 1997). However, it is not known how reliable this information may be.

The earliest most reliable illustration of the 'tail' structure dates from around 1696. The 'tail' is represented as a smoothed, elongate, rounded structure behind Castle Rock, with a gently sloping surface in a northeasterly direction (Driscoll and Yeoman 1997).

The earliest, most reliable plan of the 'tail' dates from 1725. This shows a relatively flat surface to the 'tail' with slopes to the north and the south. The northern face of the bedrock appears to have been quarried. A similar map, dated 1746, shows that the 'tail' still existed but now contained a track that ran up its centre to the gates of the Castle; there is no other information on this map. The Castle map of 1740 also suggested that quarrying of the bedrock on the 'tail' might have taken place (Driscoll and Yeoman 1997).

The Esplanade was constructed in 1753. The convex ridge of the 'tail' was contoured and made up with foundation material excavated during the building of the Royal Exchange (Wilson and Smeaton, 1904). Between 1816 and 1820 the esplanade was constructed by widening the existing surface. The sides were built up with stone and it was ornamented with turrets to the south.

A painting by Alexander Nasyth of the North Loch and Edinburgh Castle, dated at around 1780 (National Galleries of Scotland), shows that landsliding and instability did exist at this time on the northern flank of the 'tail.' However, no information could be gained from this painting of the slope between the Esplanade and Johnston Terrace.

A mid-eighteenth century view of the castle from the east shows the area now occupied by the esplanade as a gently tilted plateau, dipping to the south with a steep dip face to the north. On the north flank of the 'tail' exists a scarp, areas of hummocky ground and what appears to be loose fall material. It is possible that this may represent a landslide, with a prominent backscarp and a zone of debris accumulation (Donnelly, et al., 1998). 
The procession of George IV to the Castle on 22 August 1822 is illustrated in a painting as seen from the Half Moon Battery. The southern slope of the 'tail' is clearly visible. It is apparent from this that a plateau of fill material exists, with a southern boundary defined by an over-steepened slope. On this slope some local spalling, scree accumulation and instability may be inferred. The subsequent failure of this slope is a possibility (Donnelly et al., 1998).

Johnston Terrace was constructed in 1829. It is estimated that it was built with approximately two million cartloads of material excavated from the building of the New Town, named at the time as Geordie Boyds Mud Brig (personal communications, Historic Scotland and Edinburgh Castle). These historical events are summarised in Table 4.

\section{Ground Investigation}

In January 1998 a ground investigation was undertaken on the southern slope of the Edinburgh Castle 'tail' between the Esplanade and Johnston Terrace. This was carried out to investigate areas of apparent instability. The ground investigation was divided into separate activities that were carried out at the same time and designed to compliment each other. These consisted of visual observations of the site, trial pitting and an electrical resistivity geophysical survey (Figure 6).

\section{Visual Observations}

Ground deformations and movements on the slope were recorded (Figure 6). The main region of failure occurred immediately above the eastern portion of the 'old' retaining wall. The main backscarp of the landslide comprised a curvilinear scarp $0.24 \mathrm{~m}$ high. This was complemented by a sub-scarp, 0.1-0.2 m high with a back-tilted block, about $0.22 \mathrm{~m}$ deep. Within the zone of depletion, there exist three additional scarps, two of which were curvilinear, about $0.32 \mathrm{~m}$ high, with evidence of dilation. The third scarp was arcuate in shape, with a central subsidence depression around $1 \mathrm{~m}$ deep. The displacement was rotational and had had the effect of tilting and bulging a section of an 'old' retaining wall (Figure 6).

The 'old' retaining wall appeared to have been constructed from a single course of rough-hewn, unmortared sandstone blocks approximately $250 \mathrm{~mm}$ thick. The wall varied in (inclined) height between 3 and $7 \mathrm{~m}$, had a total length of $49 \mathrm{~m}$ and was inclined into the slope at between $50^{\circ}$ and $80^{\circ}$ to the horizontal. The material immediately backing the wall was unknown. However, steel rods used in the geophysics survey were easily pushed by hand between the wall blocks and into the material behind.

The 'old' retaining wall appeared to continue beneath the 'recently' remediated slope to the east. A trench had been formed in the 'old' retaining wall, immediately beneath the landslide. It was not known when, or why, this trench was excavated. However, it was assumed that the trench was formed to drain the landslide in an attempt to stabilise the slope. This feature allowed unstable topsoil to move downslope and accumulate at the toe of the wall.

The main scarp was observed to continue to the west along the slope. It also continued to the east of the main zone of failure, for a distance of at least $17 \mathrm{~m}$, running parallel to the slope. The eastern section of the scarp crossed the ground above a more 'recently' constructed retaining wall. Ground failure above the more 'recent' retaining wall contained a component of slippage/slumping but was dominated by a translational type of movement. In particular, the topsoil over-rode the wall. In comparison, landsliding above the 'old' retaining wall was almost completely of a rotational type. A local area of slippage was also recorded at the bottom of the 'old' retaining wall. This consisted of a scarp $0.2 \mathrm{~m}$ high and a zone of depletion $6.60 \mathrm{~m}$ wide.

A surface discharge of groundwater was observed at the point where an outcrop of bedrock was in contact with the western edge of the relatively 'recent' retaining wall. This was the only region on the slope where groundwater was observed to drain onto the surface. It was observed as a coating of water 
and a discolouration on the retaining wall and the bedrock, and by occurrence of marsh/swamp type vegetation at the foot of the slope.

\section{Trial Pitting}

A total of four trial pits were excavated on the slope between the Esplanade and Johnston Terrace (Figure 6). The dimensions of the pits varied slightly but, in general, they were a metre, or so, wide (across slope) by $0.75 \mathrm{~m}$ long (up and down slope) and no more than approximately $1.2 \mathrm{~m}$ in depth, the working safe limit for excavations without side wall supports (Irvine, 1983).

The pits were difficult to dig and were cut in a wedge shape into the slope, since this was likely to increase the stability of the pit walls. All the pits were logged; samples were taken from all stratigraphic levels. Prior to digging, the turf and immediate topsoil were removed and placed to one side. The excavated material was placed in industrial bags, placed on the side of the digging platform. All the material was suitably reinstated, compacted and restored, with the original topsoil and turf, after excavation. This method was adopted to allow the trial pitting to be undertaken with the minimum amount of visual deterioration to the slope.

Three logs were recorded for each trial pit, one for each of the three exposed walls. However, the descriptions of the pits that follow are for the pit as a whole, since there was relatively little variability of distinct horizons across the pits. Following excavation to the maximum safe depth, the bottom of each pit was hand augured. Since the slopes of Edinburgh Castle are in an area of high archaeological interest an archaeologist was present to advise and examine the range of archaeological remains and artefacts found in the pits.

The trail pits contained a thin topsoil cover with grass vegetation, underlain entirely by highly variable layered fill materials (Figure 7). This consisted of fine to coarse grained, poorly sorted, non-cohesive materials that included crushed bricks, decomposed cement, mortar and other building materials and clay-sand. Larger rock fragments were randomly distributed throughout the fill and consisted of micaceous greywacke, sandstone, shale and basalt. The matrix was finer grained, sand-rich, poorly compacted and porous with a high connectivity of the voids and vugs and, therefore, highly permeable. A variety of archaeological remains, including teeth, bones, pottery, charcoal, clay-pipes, shells, bullets, nails and coins, were also recovered.

There was both lateral and vertical variability of the fill materials. Interstitial water was observed in the form of globules coating many of the grains and fragments. Some of the coarse fragments showed slickensided surfaces, indicative of shear movements within the slope. This may represent the settling and sorting of the unconsolidated materials as it travelled down-slope, after being tipped over the esplanade.

One of the trial pits intersected the backscarp of the landslide. The backscarp coincided with a $60 \mathrm{~mm}$ thick, moderately plastic, light yellow to greenish clay. This was underlain by a $50 \mathrm{~mm}$ thick, brownorange clay. These thin clay horizons are probably highly influential in controlling the flow of groundwater through the slope. The trial pit logs are presented in (Figure 7).

\section{Geophysical Survey}

Resistivity measurements were made on the slope to determine the subsurface structures and variations in pore fluid distribution within the slope. In total, six $24 \mathrm{~m}$ long resistivity line surveys were carried out, the positions of these being shown in Figure 6. Lines 1-5 were positioned down the slope, perpendicular to the southern boundary wall of the Esplanade. Line 6 ran across the slope, parallel to the Esplanade wall. Each line consisted of twenty five electrodes spaced at $1 \mathrm{~m}$ intervals. A Wenner resistivity array was chosen for this survey due to its simplicity and speed of data acquisition and processing. A Wenner array consists of four equally spaced electrodes, the outer pair of which is used to pass current and the inner pair to determine the electrical potential difference. The survey 
proceeds by selecting electrodes 1-4 as a Wenner array and taking a measurement. Electrodes 2-5 are then selected and another measurement is taken, this procedure is repeated until all the electrodes in the line have been utilised. In order to gain a measure of how the resistivity varies with depth, the Wenner array is then widened out to a $2 \mathrm{~m}$ spacing i.e. for the first measurement electrodes $1,3,5$ and 7 are used. For the purposes of this survey the array was utilised with six different spacings corresponding to six different depths of investigation.

The raw data obtained do not relate directly to the sub-surface resistivity distribution, since the calculations assume flat homogeneous ground. For this survey the acquired data values were processed using commercial data inversion software (RES2DINV, Campus Geophysical Instruments Limited). The software performs an iterative inversion procedure to deduce a more realistic interpretation of the ground. Accurate ground topography surveys were carried out along each resistivity line and these topographic measurements were incorporated into the resistivity inversion producing resistivity maps at certain depths, projected onto the face of the slope.

Resistivity sections were created for each of the five down-slope geophysical survey lines. Each of the lines was also accurately surveyed and topographically mapped. Very large variations (several orders of magnitude) in ground resistivity were observed (Figure 8 and 9). A common observation on each section was a zone of greater conductivity in the area where landsliding and ground deformation was observed (coloured blue and green). This has been interpreted as representing zones that are more saturated, a major factor controlling ground instability. In contrast to this, regions of greater resistivity (coloured brown, red and orange) may represent zones that are relatively less saturated and therefore relatively more stable. Slope-resistivity plots, at depths of $0.25 \mathrm{~m}, 0.75 \mathrm{~m}$ and $1.27 \mathrm{~m}$ are presented in Figure 10. A zone of lower resistivity, and therefore greater saturation, can be seen to coincide with the observed region of ground deformation. With increasing depth, the level of saturation is similarly observed to increase, in the vicinity of the ground failure. Information obtained from the trial pitting and the Military Tattoo borehole investigations (Nicholson, 1975) have shown that the fill material on the slope is stratified, representing a complex history of artificial slope construction. The variation in the types of fill material, has contributed to the 'layering' of the groundwater. Perched water tables may be present in the slope in the loose, coarse-grained fill. The occurrence of clay-rich fill, as noted at trial pit A, will also control the permeability and porosity of the fill material, which will have a bearing upon ground stability.

\section{Slope Stability Analysis}

Resistivity line 1 was taken as the basis for the limit equilibrium slope stability analysis profile. The program used was 'Galena' version 2.0 (BHP Engineering Pty. Ltd., 1994). The method used was the Spencer circular analysis. This computed driving and resisting forces on a 2-D circular slip surface divided into slices. Data input consisted of ground and phreatic surface profiles, geotechnical layers, soil strength and density and slip circle radius. The program calculated the factor of safety, F, against sliding on the slip plane modelled. The Esplanade wall was taken as applying a load of $58 \mathrm{kPa}$, but was not involved in the analyses shown. The significance of the factor of safety against sliding, $\mathrm{F}$, is that movement will occur if $F$ is less than 1.0, and will not occur if $F$ is greater than 1.0. The factor of safety gives no guide to the nature of any landslide movement subsequent to failure. This depends on the geometry of the slope, the soil /rock properties and the hydrological conditions. A particular slope at $\mathrm{F}=1.0$ may fail in shear along a shear plane, or planes, and move only a small distance at which point the factor of safety just exceeds 1.0. However, this point may be one of only marginal stability, the movement being re-activated once again when driving forces exceed resisting forces. Once a shear surface has been produced it remains as a zone of weakness within the soil/rock mass.

The model used to analyse slope instability is presented in Figure 11. Table 3 gives a summary of the results. Each line represents a variation in the input parameters: strength, slip circle radius, and phreatic surface position. This reveals the sensitivity of the factor of safety to these parameters. The strength and density data were obtained for models EDIN1 and EDIN2 from Nicholson (1975) and reduced for subsequent models. It is likely that strength and density are lower for near-surface material 
compared with material obtained at depth from beneath the Esplanade. The models have employed a much simplified stratigraphy for the slope consisting of an upper 'very loose' fill and a lower 'loose' fill (the slipped fill, Layer 8, does not enter into the analyses shown), and two sandstone layers (Layers 4 and 6) (Figure 11 and Table 3). The sandstone layers and the retaining wall were assumed to have zero strength and to provide no contribution to slope stability. This is reasonable as the sandstones are jointed, and possibly disturbed, and the retaining wall is un-mortared and disturbed. These are both conservative assumptions. Thin layers, such as the clays identified in trial pits were ignored as structural units but probably play in important role in the retention of ground water and the presence of perched water within the fill.

The phreatic surface, or water table, was modelled in four different positions, two of which may be considered as extremes. The most likely position is that shown as 'shallow' (Figure 11). This represented the likely position, based on field evidence, after a period of high surface infiltration or a situation of impeded drainage. The effect of raising the phreatic surface from the 'medium' to the 'shallow' position is seen by comparing models EDIN10 and EDIN12a (Table 3). Positions of the phreatic surface outside the slip circle did not affect the factor of safety, as can be seen by comparing models EDIN1 and EDIN2 (Table 3). Placing the phreatic surface at ground level dramatically reduced the factor of safety (models EDIN6 and EDIN7) irrespective of changes to strength values (Table 3). This might occur if the phreatic surface was lying immediately behind an un-mortared retaining wall, maybe as a result of a build-up of fines behind the wall tending to block drainage.

All other factors being equal, the strength had an important effect on the results as can be seen by comparing models EDIN3, EDIN4, and EDIN5a, and models EDIN6 and EDIN7, and models EDIN12a, EDIN12b, and EDIN13 (Table 5).

The effect of decreasing the slip circle radius, and hence deepening the slip plane, can be seen by comparing models EDIN9 and EDIN10 (Table 3). The geometry of the slip circle was an estimate based on observations from the ground investigation. A $0.5 \mathrm{~m}$ deep tension crack at the slip backscarp was included in the model. The best estimate of the ground conditions is represented by model EDIN13. This yielded a factor of safety against sliding of $F=1.1$. This result agrees well with observations and with the least favourable bounds of the geotechnical parameters for fill material derived from Nicholson (1975). The iterative process represented by the preceding models was effectively a form of back analysis, given that movement had taken place, albeit of a minor nature.

\section{REMEDIATION OF THE LANDSLIDE}

Based on the site investigations, a contractor began remedial works within the ramparts above Johnston Terrace in December 1998. This involved the installation of soil nails to mitigate the effects of superficial movements and to facilitate repair of the retaining wall. A bi-axial geogrid was installed, held in place by short, hollow, self-drilling soil nails $(2 \mathrm{~m}$ long into rock where it was encountered within the lower part of the slope) and polyester fibre bolts placed within open holes ( $3.5 \mathrm{~m}$ long into overburden further up the slope). Nail heads were recessed within the soil materials. Minor filling/trimming works were also undertaken. It was also found that drainage of the slope was a problem, with surface water drainage discharging down the ramparts. Some further ground investigation work was undertaken but this was limited to inspection and probe drilling. Mudstone was encountered to the rear of the majority of the dry stone retaining wall and sandstone was observed below the wall (Figure 12).

\section{DISCUSSION}

The important landmark of Edinburgh Castle has been subject to military and engineering activities for many centuries. These have been influenced by the unusual 'crag and tail' feature of the Castle and Esplanade. Prior to placement of the fill that currently makes up the Esplanade, the bedrock profile beneath the 'tail' was subjected to severe glacial action and more recently to excavations such as 
trenches and quarries associated with sieges and fortifications over the last 500 years. However, much of the archival material can be misleading. Topographic features and fortifications may be inaccurately represented or annotated. For example, in some illustrations the 'tail' appears foreshortened when compared with its present extent. However, it is reasonably clear that the 'tail' feature up to the mid$18^{\text {th }}$ was much lower than at present, and that since then at least two stages of engineered fill have been placed, probably in 1753 and in 1816-1820, raising, widening, and hence steepening the feature to approximately its present profile. It is likely that these fills were placed and compacted by hand, cart, or animals. Looser fill may have resulted from tipping. Indications are that this historic fill is in a looser state than its modern equivalent, which would be carefully selected, screened, and compacted by machine.

The various stages of fill have obscured the bulk of the bedrock and any natural superficial deposits constituting the 'tail' feature and resulted in the present smooth-faced slope on the south side of the Esplanade. In some places sandstone bedrock outcrops at about mid slope and has been utilised in part to support the 'old' retaining wall. That which is visible is apparently in situ and undisturbed by landsliding. The weaker shales, which are inter-bedded with the sandstones, are not visible because they have undergone preferential erosion, thus forming further irregularities in the bedrock profile.

The ground investigation revealed a close correlation between the geophysical resistivity profile of the shallow fill and current landslide activity. This activity consists of both actual landslide movement of a rotational/slump nature at the eastern end of the 'old' retaining wall, and incipient activity as represented by small lateral scarps to either side of the actual landslide. The actual landslide has an arcuate backscarp in the upper part, and involves conspicuous bulging of the wall in its lower part. This has been modelled as a shallow circular rotation/slump involving shear failure of fill material with geotechnical properties selected by taking minimum values from the Military Tattoo site investigation, a best estimate of the ground water level from field observation and with a maximum depth below ground level of approximately $2 \mathrm{~m}$. Superposed on the main landslide is a very shallow mass-wasting of topsoil and fill which has flowed over the wall near to its eastern end and collected as an alluvial cone at the foot of the wall. This may have been initiated by surface runoff.

Comparison of the geophysical resistivity profiles and plan views with the location of instability features confirms that instability is closely associated with zones of low resistivity, high saturation, and hence weaker fill material, and with the surface expressions of instability. The backscarp also appears to be associated with a relatively thin clay layer, which whilst apparently not providing a likely slip plane, may influence the local ground water regime in what is otherwise a highly permeable fill material. The lateral continuation of the uppermost features of the landslide to east and west suggests that similar ground and water conditions apply there also and that these areas represent likely future slope failures. It is not possible to say on present evidence whether the landslide is a fresh feature or a re-activation of all or part of a much earlier historic feature possibly connected with the construction of the retaining walls. It appears that the fill retained by the 'new' wall, which has a slightly shallower profile than that immediately to the west, partially covers the easternmost end of the 'old' wall.

The ground investigation has provided information on the shallow ground conditions beneath the Esplanade to Johnston Terrace slope, within which the landsliding has taken place. Whilst the investigation has not revealed details of the bedrock profile beneath the fill, these do not bear on the shallow landslide features observed, with the possible exception that they may indirectly influence the ground water profile or flow.

\section{CONCLUSIONS}

- The 'tail' part of the Edinburgh Castle glacial landform known as a 'crag and tail' has been modified by man throughout the history of the castle. The original surface of the 'tail' now lies under a significant thickness of fill material. The bedrock profile beneath the fill is probably highly irregular and due to glacial erosion, subsequent periglacial denudation and the activities of man 
such as quarrying and the construction of siege excavations. There has been more than one stage of Esplanade construction. The present day embankment structure was built in 1829. It is not known when either of the retaining walls on the slope was constructed. However, it is likely that they were built in order to remediate earlier slope instability.

- A shallow slope failure of the ground took place within fill material on the slope between the Esplanade and Johnston Terrace. A rotational/slumping type of landslide occurred above the older of the two existing retaining walls. This resulted in damage to a part of the wall near to its eastern end.

- Failure took place largely within saturated, layered, cohesive to non-cohesive, loose to dense, heterogeneous fill on a slope of approximately $44^{\circ}$. The fill was highly variable in depth, and content, and appeared to have been largely engineered. This was indicated by stratification of the fill and numerous archaeological finds throughout the fill inspected in the trial pits.

- Incipient failure extended to the east and the west beyond the existing landslide. A scarp occurred on the ground surface on the slope above the 'new' retaining wall. This represented the lateral continuation of the main area of landsliding. It is likely that the fill in this part of the slope was similar to that in the area of the main landslide and that the incipient landslide indicated would be of similar type.

- The date when the most recent ground failure occurred is unknown. Failure may have taken place gradually, over a period of many years. An illustration from 1951 showed evidence of instability in the area of the most recent failure, that is, above the eastern end of the 'old' retaining wall. Falls of material from the retaining wall occurred in the late 1990's and were a hazard to pedestrians and motorists.

- The precise cause of the initiation of landsliding remains unknown. However, the following factors may have been influential in terms of producing shock or vibration which was transmitted to the slope:

1. Construction of the Castle Tunnel in 1988, which involved blasting of volcanic plug rock and the adjacent metamorphic aureole beneath the castle.

2. The site investigation drilling survey for the military tattoo stands and the preparation work for the spectator stand foundations.

- The results of the slope stability modelling were compatible with the observed features on the slope, the geophysical results, and the site investigation data for the military tattoo stands. Saturated conditions exist within the fill at shallow depth. This was confirmed by the geophysical survey and the trial pitting. Zones of low resistivity corresponded to zones of saturated and weaker fill material, which suffered slope failure or was close to failure. The slope stability model was sensitive to fill strength and the level of the water table.

- A large, deep-seated landslide exists on the north side of the Esplanade. A similar landslide may exist on the south side of the Esplanade. However, there is currently no evidence for this and, if present, it is probably unrelated to the shallow landsliding described here.

- Remedial engineering works were required to stabilise the slope. These included:

1. Drainage of the slope.

2. Soil nailing.

3. Repair of the 'old' retaining wall. 


\section{ACKNOWLEDGEMENTS}

This paper is published with the permission of Halcrow Group Limited and the Executive Director of the British Geological Survey (NERC) and with the agreement of Historic Scotland. We are grateful to The Society of Antiquaries of Scotland for permission to reproduce Figures 4 and 5, to Nigel Ruckley for his assistance with historical and geological matters, to CAN Limited for permission to reproduce Figure 12 and to Lothian Webster of Historic Scotland for advice and comment at various stages of the work. The views expressed in this paper are not necessarily those of the Halcrow Group.

\section{REFERENCES}

BHP Engineering Pty. Ltd. (1994). Galena (version 2). Slope Stability Analysis System (CBHP Engineering Pty. Ltd.

British Geological Survey (1965). 1:10,560 scale geological map sheets NT 27 SW and NT 27 SE.

Charles, JA. (1993). Building on Fill: Geotechnical Aspects. Building Research Establishment, Report No. BR 230.

Cheeney, RF. (1977). Report on aspects of the geology of Edinburgh Castle Rock. University of Edinburgh, unpublished report.

Davies, P. (1991). Engineering geology in Edinburgh: the Castle Tunnel. The Edinburgh Geologist. No. 26, 2-11.

Donnelly, LJ, Flint, RC, Tulloch, GJ, Hobbs, PRN, Ruckley, N and Jackson, PD. (1998). Edinburgh Castle: Esplanade to Johnston Terrace Slope Stability: Ground Investigation Report. British Geological Survey Technical Report WN/98/5.

Douglas, TH and Keeble, S. (1990). Design and construction of a new service tunnel at Edinburgh Castle. Tunnel Construction ' 90.

Driscoll, ST and Yeoman, PA. (1997). Excavation within Edinburgh Castle in 1988-91. Society of Antiquaries of Scotland, Monograph Series No. 12, Edinburgh.

Irvine, D. J. (1983). Trenching Practice. Construction Industry Research and Information Association, London, Report No 97.

MacLaren, C. (1984). The geology of Edinburgh and its environs: Castle Hill. The Edinburgh Geologist. No. 15, Spring, 10-26.

Mitchell, GH. and Mykura, W. (1962). The geology of the neighbourhood of Edinburgh. Memoir of the Geological Survey of Scotland. London: Her Majesty's Stationery Office.

Mitchell, GH, Walton, EK and Grant, D. (1960). Edinburgh geology. Edinburgh and London: Oliver and Boyd.

Nicholson, R. (Site Investigation Limited) (1975). Site Investigation Report. Edinburgh Military Tattoo. (Unpublished).

Price, DG and Knill, JL. (1967). The engineering geology of Edinburgh Castle Rock. Geotechnique, 17, 411-432.

Ruckley, NA. (1991). Geological and geomorphological factors influencing the form and development of Edinburgh Castle. The Edinburgh Geologist. No. 26, Autumn, 18-25.

Ruckley, NA. (1997). The geological setting. In: Driscoll, S. T. And Yeoman, P. A. (eds). Excavation within Edinburgh Castle in 1988-91. Society of Antiquaries of Scotland, Edinburgh, Monograph Series No. 12.

Sissons, JB. (1971). The geomorphology of central Edinburgh. Scottish Geographical Magazine, 87, 185-196.

Tait, D. (1945). Geological notes on (a) The Nor Loch and (b) The Fore Well in Edinburgh Castle. Transactions of the Edinburgh Geological Society, 14, 28-33.

Wilson, D and Smeaton, O. (1904). Edinburgh and its story. Memorials of Edinburgh in Olden Times, $144 \mathrm{p}$. 


\section{Tables}

Table 1. Standard Penetration Test results, from the 1975 site investigations (borehole locations are shown in Figure 5).

Table 2. Undrained Triaxial Compresion tests results from the 1975 site investigations (borehole locations are shown in Figure 5).

Table 3. Undrained shear box tests results from the 1975 site investigations borehole locations are shown in Figure 5).

Table 4. Historic events at Edinburgh Castle that may have influenced the development of the 'tail' and Esplanade

Table 5. Results of the slope stability analysis 


\section{Figures}

Figure 1 Glacial eroded 'crag and tail' structure on which Edinburgh Castle and the esplanade are built. The columnar jointed basalt plug supports the castle. Landsliding and apparent instability occurs on the 'tail' on the Johnston Terrace slope; showing falling masonry, bulging and general instability of the 'old' retaining wall. The unaffected slope can be seen above the backscarp, being investigated by a trial pit.

Figure 2 The solid and drift geology of central Edinburgh (based on British Geological Survey, 1965) (after Sissons, 1967 and Ruckley, 1997).

Figure 3 Location of the Military Tattoo site investigation boreholes (after Nicholson, 1975).

Figure $4 \quad$ View of Edinburgh castle around 1700, showing defensive walls and other engineered structures. It is not known if these were actually constructed (source: The British Library. Reproduced by Driscoll and Yeoman, 1997).

Figure 5 Edinburgh Castle and Johnston Terrace around 1647, showing medieval ditches and cannon batteries in the bedrock of the 'tail' (source: Edinburgh Central Library. Reproduced by Driscoll and Yeoman, 1997).

Figure $6 \quad$ Location of field observations, resistivity survey lines and the trial pits.

Figure $7 \quad$ Trial pit logs.

Figure 8 Resistivity data and topographical observations for resistivity survey lines 1 to 3.

Figure 9 Resistivity data and topographical observations for resistivity survey lines 4 to 6.

Figure $10 \quad$ Slope resistivity plots for depths $0.25 \mathrm{~m}, 0.75 \mathrm{~m}$ and $1.27 \mathrm{~m}$.

Figure 11 Slope stability analyses and schematic mid section of the Esplanade - Johnston Terrace slope.

Figure 12 Soil nailing at Edinburgh Castle to stabilise of the Esplanade - Johnston Terrace slope (photograph, CAN Ltd). 